\title{
To the memory of Dr. Raúl Aceves Ortega
}

Raúl Aceves-Lozano, ${ }^{1}$ Margarita Aceves-Lozano, ${ }^{2}$ Vianca Seleste Contreras-Cordero, ${ }^{3}$ Verónica Alexandra Sánchez-López, ${ }^{3}$ Tom Jilmer Castillo-Valverde, ${ }^{3}$ Clotilde Fuentes-Orozco ${ }^{3}$, and Alejandro González-Ojeda ${ }^{3 *}$

${ }^{1}$ Universidad de Guadalajara, University Center of Social Sciences and Humanities, Department of Literary Studies, Jalisco; ${ }^{2 H i l t o n ~ H o t e l, ~}$ Sales Management, Mexico City; ${ }^{3}$ Instituto Mexicano del Seguro Social, Centro Médico Nacional de Occidente, Specialty Hospital, Guadalajara, Jalisco. Mexico

\section{Academician Doctor Raúl Aceves Ortega education}

He started his basic education at Morelos School and finished it at the Institute of Sciences. He began his medical training at the Autonomous University of Guadalajara School of Medicine. Then he went to the Faculty of Medicine of the National Autonomous University of Mexico for the next four years, until he graduated on June 22, 1944. He did his social service in the town of Mexticacán, Jalisco. After finishing his service, he stayed in Mexico City and attended the Dermatology Department of the General Hospital, Pabellón 11, headed by Dr. Salvador González Herrejón, and whose dermatology courses he attended, as well as those taught at the same place by Dr. Vicente Ramírez.

On his return to Guadalajara in 1946, he practiced general medicine for a few months, and then he was invited to collaborate in leprosy and dermatological outpatient services by Dr. José Barba Rubio, head of the Anti-Leprosy Dispensary "Doctor Salvador Garciadiego", who had already started the construction of the Dermatological Institute since early 1947. He started his activities at the dispensary, where he served daily from 9 to 13 hours, voluntarily and without any economic remuneration or official appointment. In the same way, he continued providing his services at the Dermatological Institute when its construction allowed, intervening in all its activities, either healthcare related, academic nature, or educational and research associated.
In 1948, Dr. Aceves was appointed deputy professor of the dermatology chair, whose head was Dr. Manuel Castañeda. The subject was taught in the third year medical curriculum and was divided in two independent sessions: twice a week, it was taughte by Dr. Castañeda, and the lessons were theoretical, and three times a week, it was taught by Dr. Aceves, with the sessions mainly being practical. Dr. Raúl Aceves taught his course in the indicated form until 1953, कbut he continued with his appointment as deputy professor until 1964. He collaborated closely with other physicians, such as Dr. Julio Flores Navarro, who wasnot a dermatologist but an excellent internist with a vast experience in leprosy, and with interns Mario Gallärdo Carbajal and Gonzalo Ramírez Ponce de León, who were doing their internship and preparing their graduation theses. In addition to his teaching activifies, Dr. Raúl Aceves supported the incipient Dermatological Institute as a specialist in Hansen's disease in its different presentations. In those days, patients affected with this condition were quite common; even today, this condition has not disappeared from the medical setting.

In 1949 he was invited by Dr. Ángel Leaño, secrełary of the Autonomous University of Guadalajara School of Medicine, to teach the Clinical Dermatology subject at that faculty, an invitation he accepted. He started the course immediately that same year, teaching it daily in the morning. The Faculty of Medicine had then a small hospital, largely dedicated to obstetrics and gynecology, and had no outpatient services. Since patients with skin
Correspondence:

*Alejandro González-Ojeda

E-mail: avygail5@gmail.com
Date of reception: 15-07-2019

Date of acceptance: 20-08-2019

DOI: 10.24875/GMM.M20000344
Gac Med Mex. 2019;155:52‡528 Contents available at PubMed www.gacetamedicademexico.com license (http://creativecommons.org/licenses/by-nc-nd/4.0/). 
diseases were necessary for the dermatology course, Dr. Raúl Aceves opened the outpatient services, which soon grew. Since the premises were insufficient, he then promoted and managed to build an outpatient department at the "Ramón Garibay" Hospital, which has several offices and a classroom for lessons and meetings; he was head of the department from 1954 to 1956. In addition, Dr. Raúl Aceves Ortega was appointed director of the "Ramón Garibay" Hospital from 1956 to 1958. During his administration, the hospital increased its capacity, organized new departments, and improved in many aspects. He was head of the Dermatology Department at that hospital since its foundation in 1950 and until 1974 when the department was transferred to the "Angel Leaño" Hospital, which had been recently built by the university, where he continued being head of the renewed Dermatology Department.

Shortly afterward, he was appointed head of the Department of Dermatology of the Faculty of Medicine, which included the same hospital duties and the position of department chair, as well as administrative work. He performed all these duties until 1990 when Dr. Raúl Aceves retired from teaching and healthcare-related activities at the Faculty of Medicine of the Autonomous University of Guadalajara. He was also appointed professor of dermatology postgraduate courses at the Faculty of Medicine of the Autonomous University of Guadalajara since its founding in 1975 and until 1990; prior to 1975, this type of teaching was not regulated and was carried out by mentoring.

Dr. Aceves Ortega was a consultant for several hospitals in Guadalajara, such as the Regional Hospital of the Pacific from 1951 to 1967, at the stage at which this center provided hospital services to railroad workers. In addition to that, he also consulted at the Hospital, since its foundation in 1951; Hospital Infantil Guadalupano from 1950 to 1966, Hospital del Carmen, from 1953 to 1970, where he also served as director from 1958 to 1963, and at the Santa Maria Chapalita. All hospitals located in the metropolitan area of Guadalajara and Zapopan.

He participated as a professor in multiple postgraduate courses taught by the Mexican Society of Dermatology in Mexico City, from 1959 to 1988 . He also served as a visitor professor at multiple institutions such as the School of Medicine of the Autonomous University of Nuevo León in April 1976, the Faculty of Medicine of the Autonomous University of Aguascalientes in 1976, the University of Michoacán in 1978 and 1979, the University of Guanajuato in 1957, and at the Autonomous University of Zacatecas in 1970.

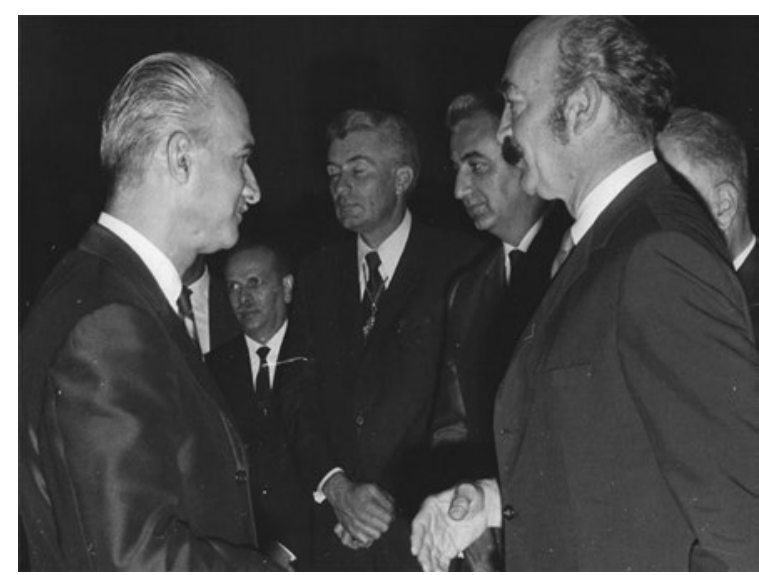

Figure 1. Dr. Raúl Aceves Ortega admission to the National Academy of Medicine of Mexico. Academician doctor José Laguna García, president of the Academy, welcomed the new academician on September 2, 1970.

In the late 1980s, he organized and directed symposiums and seminars on dermatology, dermatopafthology and pediatric dermatology, which were of great interest due to their great clinical content.

Dr. Raúl Aceves was a member of various scientific societies such as the Mexican Society of Dermatology (1952 to 2017), a founding member of the Dermatofogy Society of Guadalajara (1984 to 2017) and also was member of other national and foreign societies. Among the international associations, the Royal Society of Medicine of London and the Pacific Dermatologic Association of the United States stand out. He was admitted to the National Academy of Medicine of Mexico on September 2, 1970, under the presidency of the Academician Dr. José Laguna García (Fig. 1). He wwas an outstanding academician, with a high sense of $\& 0 l-$ laboration, and shared his knowledge and experiences in multiple forums organized by our academy.

$\mathrm{He}$ attended numerous national and international congresses of his specialty, where he held different positions and where he participated in the presentation of many works. He gave more than 200 important conferences in medical societies, medical schools, hospitals, courses, round tables, seminars, symposia, meetings, etc., both at pre and postgraduate levet: $\mathrm{He}$ directed more than 40 undergraduate and more than 20 postgraduate theses.

Dr. Raúl Aceves had an intense scientific activity. He published around 150 medical works on the specialty in national and international journals, as welt as several dermatology texts and unpublished dermätology works. Table 1 shows some publications thatare representative of Dr. Aceves Ortega academic work. 
Table 1. Representative works published by academician doctor Raúl Aceves Ortega

Boletín de la Facultad de Medicina, Universidad Autónoma de

Tratamiento de la Lepra por las Sulfonas.

Guadalajara

Boletín de la Facultad de Medicina, Universidad Autónoma de Transmisión de la Lepra al niño.

Guadalajara

Boletín de la Facultad de Medicina, Universidad Autónoma de Tratamiento de la Lepra por las Thiosemicarbazonas.

Guadalajara

Boletín de la Facultad de Medicina, Universidad Autónoma de

La leprominorreacción.

Guadalajara

Boletín de la Facultad de Medicina, Universidad Autónoma de Las tiñas.

Guadalajara

La Prensa Médica Mexicana

La Prensa Médica Mexicana

La Prensa Médica Mexicana

Revista de Medicina y Ciencias Afines

La Prensa Médica Mexicana

Dermatología, Revista Mexicana

Sonderabdruck aus der Schweizerischen Medizinischen Wochenschrift

El Médico

El Médico

Semana Médica de Mexico

Semana Médica de Mexico

Semana Médica de Mexico

Memorias del III Congreso Ibero Latinoamericano de Dermatología, Mexico

La Prensa Médica Mexicana

Semana Médica de Mexico

Semana Médica de Mexico

Boletín Médico de la Universidad Autónoma de Guadalajara

Boletín Médico de la Universidad Autónoma de Guadalajara

Semana Médica de Mexico

Semana Médica de Mexico

Dermatología, Revista Mexicana

Hidrocortisone ointment in Dermatoses.

Dermatological Service of the Hospital Ramon Garibay in Guadalajara; comments on 1300 cases studied from 1951 to 1954.

La Prednisolona -Neomicina en el tratamiento de la Neurodermatitis diseminada y la Dermatitis por contacto.

El Vioformo en Algunas Dermatosis.

Dermatitis eczematosas.

Tratamiento de Algunas Dermatosis Piógenas con la Asociación Novobiocina Tetraciclina.

Konservative Behandlung der Nagelmykosen mit Onycho-Phytex.

Dermatosis profesional por Hidroquinona.

Tratamiento de algunas Dermatosis Piógenas con Novobicina.

La Hidrocortisona - Succinato Sódico- Intravenosa en Dermatología.

Lupus eritematoso sistémico.

La Trifluoperazina en Tratamiento de Diversas Afecciones Psicocutáneas.

Las Micosis Profundas en Nuestro Medio.

Neo-oxylone (21-desoxy-9

alpha-fluoro-6-methylprednisolone), a new corticosteroid for topical application in some dermatoses.

Dermatitis Seborreica Infantil.

Valoración Clínica de un Nuevo Antihistamínico, Maleato de la 2-1-2 (2-Dimetilaminoetil)-3-Indetil)-Etil) Piridina, en las Dermatosis Pruriginosas.

Griseofulvina en Micosis Superficiales.

Griseofulvina en Micosis Profundas.

Flufenazina en Dermatología.

El Vasculat en el Tratamiento del "Complejo de Pierna".

Coccidioidomicosis, Comunicación de un Caso. 
Gaceta Médica de México. 2019;155

Table 1. Representative works published by academician doctor Raúl Aceves Ortega (Continued)

Journal

Title

Dermatología, Revista Mexicana

Mesa Redonda sobre Corticoesteroides.

Dermatología, Revista Mexicana

El factor psicógeno en las dermatosis y su tratamiento psicotrópico.

Sociedad Mexicana de Dermatología

Micetomas, Análisis de 75 Casos Estudiados en la Ciudad de Guadalajara.

Semana Médica de Mexico

El Acetónido de Fluocinolona en el Tratamiento Tópico de Diversas Dermatosis.

Medicina Mexicana

Dermatología, Revista Mexicana

New therapeutic method for psoriasis by means of the topical application of fluocinolone acetonide.

Prurigo Nodular de Hyde.

Medicina Mexicana

Fluocinolone acetonide with occlusive dressing in the topical treatment of various dermatoses.

Sociedad Mexicana de Dermatología.

Etiopatogenia y Tratamiento del Vitíligo, Análisis de 500 casos.

Medicina Mexicana

Tratamiento de Algunas Formas de Dermatitis con la Combinación de Acetónido de Fluocinolona-ladoclorohidroxiquina.

Medicina Mexicana

Fluocinolone acetonide and iodochlorhydroxyquin.

Dermatología, Revista Mexicana

Memorias del II Congreso Mexicano de Dermatología.

Prurito, Sintomatología, Diagnóstico y Tratamiento.

Alopecia Areata, Estudio de 200 Casos no Seleccionados.

Dermatología, Revista Mexicana

La Prensa Médica Mexicana

La Prensa Médica Mexicana

Medicina Mexicana

Sociedad Mexicana de Dermatología

Dermatología Revista Mexicana

Dermatología Revista Mexicana

Dermatología Revista Mexicana

Sociedad Mexicana de Dermatología

Sociedad Mexicana de Dermatología

Dome Laboratorios (memorias)

Dermatología Revista Mexicana

Dermatología Revista Mexicana

Dermatología Revista Mexicana

Sociedad Mexicana de Dermatología

Prurito, Etiopatogenia.

Nuevo Fungistático para Uso Tópico, el 3 , el 3,5-Dicloro-4-Fluorotiocarbanilida.

Queilosis. Estudio de 200 casos.

Clinical evaluation of 0.01 per cent solution of fluocinolone acetonide in propylene glycol.

Melanosis de la Cara, Estudios de 500 casos.

La pelagra en México y sus relaciones con la nutrición y medicina era precortesiana.

La pelagra en México y sus relaciones con la nutrición y medicina colonial.

Notas para la Historia de la pelagra sus relaciones con la nutrición y la medicina en México.

Memorias del cuarto congreso mexicano dermatología Rosácea estudio general.

Patogenia y tratamiento del acné.

Dermatitis por Drogas Comunes.

La pelagra en México y sus relaciones con la nutrición y medicina época independiente.

La sífilis, diagnóstico y tratamiento.

Epidemiología de las micosis profundas.

Memorias del V congreso mexicano de Dermatología. Epidemiología de las micosis profundas. 


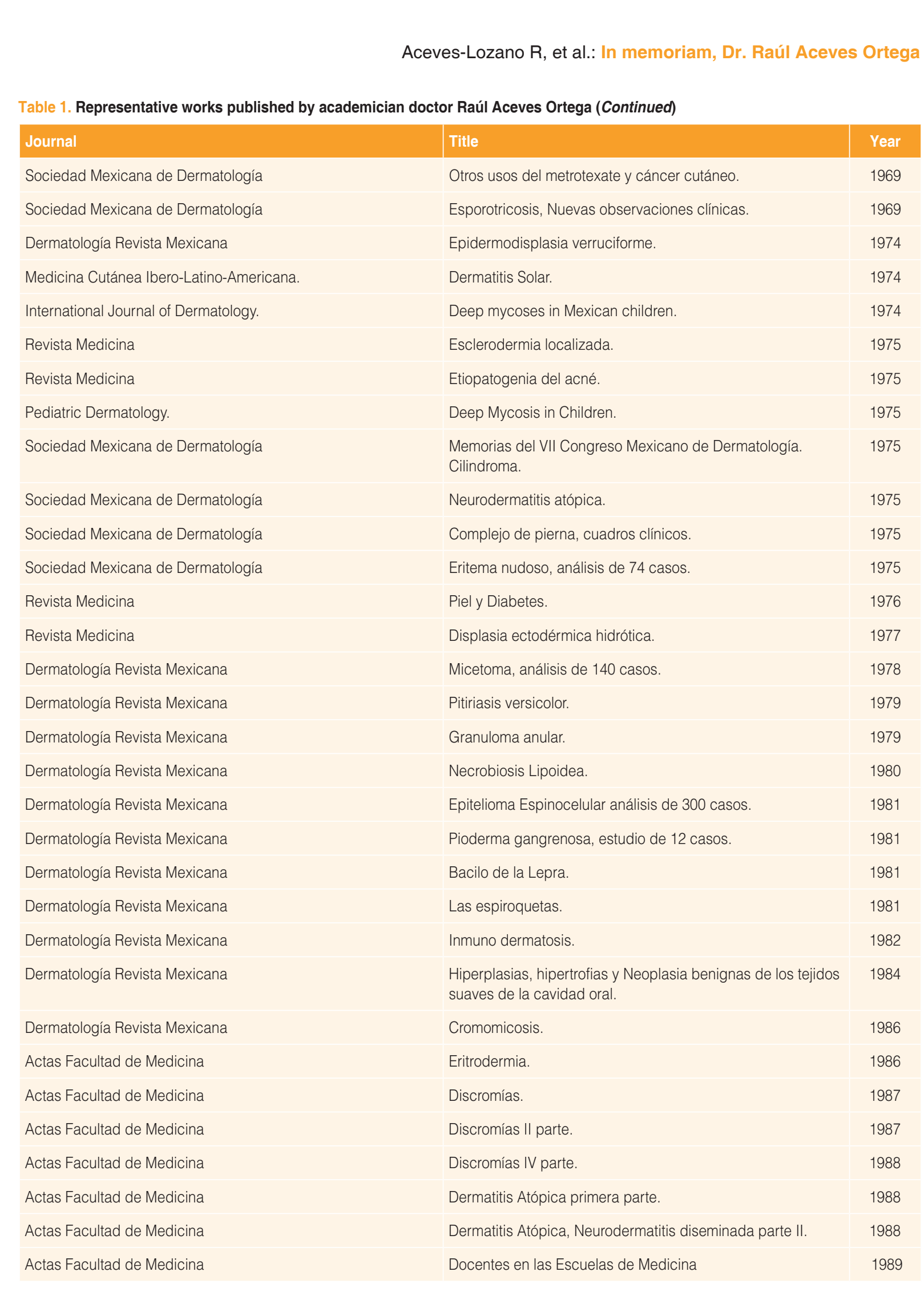

He was a member of the editorial bodies of journals of his specialty and directed some scientific dissemination publications such as Medical Journal of the University of Guadalajara from 1969 to 1972.
His great fondness for the history of Mexico and Jalisco, in particular, let him to acquire vast knowledge, which he expressed in essays, articles and books. He was a member of the Mexican Society of 
History and Philosophy of Medicine from 1964 to 2017, and founder of the Jalisco Society of History of Medicine (1964 to 1970).

Dr. Raúl Aceves was a founding member of the Mexican Council of Dermatology in Mexico City in 1974, which he chaired from 1977 to 1979 , and was an active member of it until 1999, the year he became an honorary member. He belonged to the main Dermatology Societies of Guadalajara, the Mexican Society of Dermatology, as well as to the Ibero-Latin American Society, in some of them as founding member. He was also a member of the Royal Society of Medicine of England.

He belonged to several societies of historical studies: the Center for Historical Studies "Fray Antonio Tello", of Guadalajara, the Society of Highland Studies, and the Jalisco Society of History of Medicine (founding member).

He left several unpublished books on the history of medicine: Historia General de la Sifilis (General History of Syphilis), Historia de la Lepra en Jalisco (History of Leprosy in Jalisco), La Pelagra en México (Pellagra in Mexico), and La Dermatología en Jalisco (Dermatology in Jalisco). Apart from medicine, his second passion was the history of Mexico, particularly of the highland region, from where he was native. The fruits of the time he devoted to historical research were the following publications:

- Hospitales de Indios y otras Fundacione Civiles y Religiosas en Nueva Galicia (Hospitals of Indians and other Civil and Religious Foundations in Nueva Galicia), University of Guadalajara editorial, 2004.

- Médicos de Guadalajara durante la época colonial (Doctors of Guadalajara during the Colonial era), Ministry of Culture of Jalisco, Col Voz de la Tierra, Guadalajara, 2006.

- Primitivos pobladores indígenas e hispanos de los Altos de Jalisco (Primitive indigenous and Hispanic residents of Los Altos de Jalisco), Amaroma Ediciones, Guadalajara, 2005.

- Los Aceves de los Altos de Jalisco (The Aceves Family from Los Altos de Jalisco). Amaroma Ediciones, Guadalajara, 2006.

In addition to his vast academic, teaching, and healthcare-related work, since 1947, he started his private professional practice by installing his first office in the building located at the corner of Juárez and Pavo, in downtown Guadalajara. In 1950 he moved to the Barreto building, and in 1960 he settled permanently at his office in Morelos Street \# 1586-102 where he gave medical consultations until 2010 .
Certainly, it is peculiar knowing Dr. Raúl Aceves' professional life, who served at the main publicrand private universities: the National Autonomous University of Mexico, the Autonomous University of Guadałajara and as a historian, at the Benemérita Universídad de Guadalajara. In our days, this mobility would not seem strange; however, for the times he lived in, it might have been unusual.

Finally, Dr. Raúl Aceves Ortega was a worthy member of the National Medicine Academy of Mexico, in the west of the country. He achieved a perfect balance between teaching, research and, patient care. Even today, many colleagues remember him as an efficicacious doctor with a high sense of commitment to the care of his patients. At least 40 generations of medical graduates from the Autonomous University of Guâdalajara attest to his professionalism and adherence to medical education. We will always remember Dr. Aceves Ortega for the significance of his works.

\section{Family life}

On behalf of the Aceves Lozano family, we wish to sincerely thank the National Medicine Academy for their interest in paying tribute to the memory of-our father. We also thank the generosity and enthusiasm of Dr. Alejandro González Ojeda and his team, who agreed to collaborate in this tribute, despite not having known our father while he was alive.

Native from Tepatitlán, Jalisco, where he was borâ on September 21, 1919, since he was two years old he moved to Guadalajara with his family. His parents were Félix Aceves López and Emilia Ortega Aceves; he was the eldest of nine siblings. On January 27, 1951 he married Margarita Lozano Barajas, with whom he begot seven children in the following order: Raúl, Sergio, Jơrge Eduardo, Ricardo, Margarita, Gabriela, and Alberto de Jesús. From his offspring, he had 12 grandchildren: Ana Sofía, María Inés, Regina, Santiago, Sebastián, Constanza, Igor, Diego, Rodrigo, Andrés, Alberto, and Garolina, and a great-grandson, Benjamín.

He mainly liked to read works of Mexican historyand general history, as well as literary works, detective novels, art books, essays, biographies, magazines, etcetera. He came to form an valuable library thatoccupied two large rooms in his house. His second passion was research and writing scientific articles and historical works, of which four were published.

Another of his passions was traveling with his wife, family, and friends, with whom he made trips through Mexico, the United States, Canada, and Europe, 
especially enjoying his trip to Spain. Particularly, I had the opportunity to make several trips with my parents, which I enjoyed very much since my father explained to us the history of each one of those places, which instilled in me the taste for history as well.

He was not very fond of sports or shows; only when he was young he practiced frontenis and bowling; he really enjoyed music, particularly classical music, which he had a good collection of.

We remember a lot the time our father spent with all his children on weekends doing several family outings. When we were very young, he used to take us to La Primavera park and different parks in the city. To Chapala in the summer, visits to Tepatitlán and the ranch of my paternal grandfather, Felix Aceves, and Christmas and birthday gatherings or regarding any family celebration, which would never go amiss. $\mathrm{He}$ was an extremely responsible father, hardworking, studious, educated, and had a strong character. However, he was very fair and dedicated to his children and wife, with his marriage lasting 66 years.

Both as a doctor and person he was very attentive. He always gave his support as a doctor to anyone who asked for it and all this combined with another of his passions, teaching and research. He was a very practical person, he liked to do all kinds of manual work and homemade arrangements in everything within his reach. At the end of his life, he developed other hobbies: crosswords, puzzles and the inevitable TV movie after dinner.

\section{Raúl Aceves Lozano testimonial}

I got to be the firstborn of his children and to very proudly bear his name, which caused some confusion as it was to be expected, since often he was congratulated "for his new poetry book" (which was actually mine) or I was asked about some medical issue. Sometimes, people thought I was his "younger brother" (due to my abundantly gray but sparse hair). I always shared with him an interchangeable identity as a professional and writer. This didn't deny our differences either: if he was fascinated by the history of Mexico, I was fascinated by literature. Moreover, he was an important university professor of great prestige, I have never been more than an average teacher; if he practiced the trade of solitude in his library, I practiced the trade of sociability in multiple environments. Similarities and differences between a father and a son, which are quite natural; similarities that allowed me to share with him many pleasures (reading, movies, puzzles) and many contrary opinions in various topics and issues of life.

$\mathrm{He}$ was, to me, a great example of righteousness, work, discipline, love for knowledge and culture, of openness, and a critical attitude. He was a great teacher, generous, hard, strong, incorruptible, and sometimes, fearsome. It was not easy to be his friend or reach the ground of confidences, because he was very clear about his role as head of the family and father, which always made him keep a psychological distance. However casionally, he spontaneously opened up and taked about many personal topics, memories, joyful orcunpleasant experiences, anecdotes, which he narrated with pleasure to his improvised family audience. He never wanted to write his memoirs because, frank as he. Was, surely in more than one he might come off badly, and we never thought of recording his talks to have a file with his voice. Too bad, because it would have been a very good memory (now, closing my eyes and remembering him, I can hear again his peculiar tone of voice, so clearand firm and full of emotional nuances).

Now, I come to think about all the conversations I was never able to have with him, about all the trips I never made with him, about everything I could have done with him. That is why thinking about him gives me great nostalgia, rather than sadness. I am glad to have been his son for so many years, despite allithe ups and downs in our relationship; I am proud to have had such a complete and accomplished father, whose stature I am reach. I feel deeply grateful to him as ivell as to my mother because they gave me this hugeand complicated gift that is life. From the place or spiritual dimension where they are now, I keep feeling their protective, loving presence, guiding my way, just as other guardian angels. With love Chato.

\section{Testimonials from some of his grandchildren}

\section{Constanza}

I am not going to tell you about the doctor; going to tell you about grandpa, my tito.

He was a man full of traditions and values. My tito (as we affectionately refer to many of our grandfathers) was the most handsome, wise, and loving man in the world. He always had a smile hidden behin đhhis big and perfect white mustache; he always had an answer for every silly question I asked and a story to tell. When I was a little girl of five or six years I 


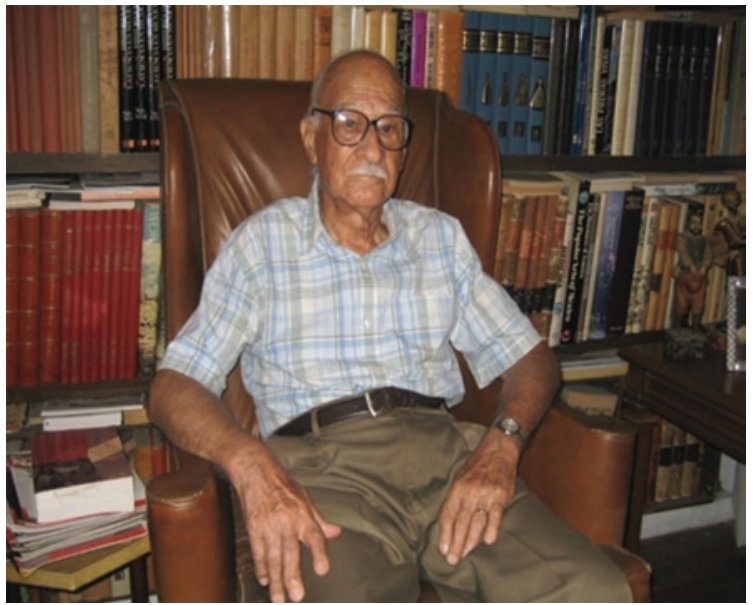

Figure 2. Library and favorite chair of academician doctor Raúl Aceves Ortega, who died in the tranquility of his home and, his favorite place, on May 21, 2017, at the age of 97 years and eight months.

remember sitting on his knees like on piggyback, as if I was galloping and he started singing songs and telling us stories about the ranch. We laughed a lot.

He was a patient man since he always spent hours explaining to me my math homework and did not give up until I understood. He was a grandpa of those who build a wooden house for you in the garden under the lemon tree, or takes his grandchildren to the corner shop to buy everything we wanted; he used to take us to ride the tricycle to the sidewalk around the house or to the playground.

When I was about 32, I assisted him in the removal of a wart from my dad; I saw that he was happy that I was assisting him, and when we finished, he told me that I had been the best assistant and gave me a kiss. I felt the happiest granddaughter! There are so many beautiful things I remember that I could go on for hours, but I can tell you that he was a fantastic grandfather! Full of virtues, dedicated to his family and his career.

\section{Julian Igor Aceves}

I remember my grandfather Raúl (tito) as a unit that was inseparable of his home, his large family, his library with thousands of books and his garden,, my sister's, my cousins' and my own favorite space when we were children. As children, we saw it as a small forest where you could hide, play under the pomegranate trees and run around the pile (already without water and with danger of falling into it). Memorable are the corridors of the Avenida La Paz big house, witnesses that at least on tricycle (since I never learned to ride a bike) I had my good races, with my grandfather always overseeing everything with a book in his hand (surely history of Mexico). Tired of runhing and playing, it was time for a jericaya, or perhaps the vanilla ice cream prepared by my grandmother M̆argarita, inseparable lifetime companion of tito. Many times, during meals, he asked me to sing for him. From him, I learned my first ranchero songs (fortunately, we keep audiovisual documents). Now think it was like an omen since years later I would work a few years in a mariachi band in Spain, performing those same first songs, which my grandfather taught me, in a warm atmosphere of family life.

On May 21, 2017, he died sitting on his favorite armchair in the library (Fig. 2), after reading the newspaper as he used to do it. He left a very important legacy for each of his children, mainly honesty, loyalty; and love for his family.

We conclude our participation in this tribute, thanking again the National Medicine Academy of Mexico Dr. Alejandro González Ojeda and his group, for their great support to carry out the semblance of my father, Raúl Aceves Ortega, in recognition of his 66 years of academic life. 